\title{
Optimization of the University and College Teaching Management Team Building along with the Rapid Development of Higher Education
}

\author{
Sainan Zhang \\ Department of Teaching Affairs, \\ Jilin Agricultural University, \\ Changchun, China \\ Email: Zhangsainan8304@126.com
}

\begin{abstract}
The historical review of higher education development shows that China's higher education has entered a rapid development period. Under the condition, it is imperative to optimize the university and college teaching management team structure. In view of the rapid development of the current higher education, this paper puts forward several suggestions as to how to optimize the university and college teaching management team building, improve teachers' qualities and skills and boost the development of higher education at an attempt to provide theoretical bases for the building and development of the university and college teaching management team.
\end{abstract}

\section{Keywords-higher education; development; management team building; optimization}

\section{HISTORICAL REVIEW OF CHINA'S HIGHER EDUCATION DEVELOPMENT}

Since 2006, China's higher education has been attached great importance by the Communist Party of China (CPC) and national government, and achieved rapid development. In the collective learning of Central Political Bureau of the CPC on August 29, 2006, the former President HU Jintao emphasized on unswervingly implementing the strategy of rejuvenating the country through science and education, and human resource development, which gave priority to educational development, promoted sustainable development of education and firmed up Chinese determination to build China into a country rich in human resources. On May 10, 2006, the State Council held 135 executive meetings, pointing out that the higher education should implement the scientific development outlook, focus on improving its quality, properly control its enrolment scale expansion and maintain the schooling scale at a stable level. On the executive meeting held by the State Council on December 27, 2006, the national 11th Five-Year Education Development Program was deliberated and passed, and the 11th Five-Year Higher Education Development Goals were put forth: to enhance education for all-around development, to consolidate the schooling scale and to improve the educational quality. On November 7, 2006, the State Council held the National Vocational Education Meeting, in which the former Premiere WEN Jiabao emphasized on three properties of vocational education, namely professionalism, sociality and affinity to the people. Professionalism means education is to bring up practical talents. Sociality means education should promote social employment. Affinity to the people means education is oriented towards all people. On May 31, 2010, YUAN Guiren, Education Minister of the People's Republic of China, pointed out in his speech themed on "Situation and Challenges of China's Higher Education" that to put education at a strategic place and give priority to its development is a major guideline that Chinese socialist modernization should stick to for a long term ${ }^{[1]}$. Since the mid1990s, Chinese government has regarded the strategy of rejuvenating the country through science and education and through human resource development, and the strategy of sustainable development as three national strategies to keep on updating the deployment for the reform and development of higher education. The total scale of higher education had increased from 7.68 million in 1998 to 29.79 million in 2009. During the same period, the gross enrollment rate had increased from $10 \%$ to $24.2 \%$; and the number of students graduating from universities and colleges had exceeded 6 million from less than 1 million in 1999.

With the increasing scale of higher education, the cultivation quality of talents should always be the focus, with the teaching quality assurance system continuously improved, the higher education structure continuity optimized and the schooling characteristics and schooling level highlighted. The above paragraph shows that the Chinese government regards the people as the theme and proceeds from social equality to publicize and popularize education and promote the education equality and balanced development.

\section{NECESSITY TO OPTIMIZE THE UNIVERSITY AND COLLEGE TEACHING MANAGEMENT TEAM BUILDING}

\section{A. National policy orientation}

The national policy orientation is to match with the changing development situation of universities and colleges and the rapid development of higher education. The building and development of the university and college teaching management team should respond to the changing situations. This is the guarantee for the realization of the modernization of Chinese higher education, and the 
prerequisite for the improvement of higher education and teaching level. Through concept update and vigorous exploration, the higher education university and college teaching management team building can be optimized so as to better safeguard the acceleration of higher education ${ }^{[2]}$.

\section{B. Requirement of international situation}

Currently, with the rapid development of scientific technology, the knowledge-driven economy has taken shape and the competition of the comprehensive national strength is becoming increasingly fierce. Higher education plays an important role in the improvement of the comprehensive national strength. The national strength is more and more decided by the qualities of laborers, and the quality and quantity of various talents. Under the situation, it is imperative for China to bring up new talents to respond to challenges of the 21st century. Therefore, the optimization of the higher education and teaching team is the top priority of the talent cultivation quality.

\section{Optimization of the teaching management team building driven by the optimization of university and college teaching management system}

The innovation of the university and college teaching management system puts forward new requirements of the university and college teaching management team building, makes new adjustments and optimizes the university and college education and teaching team building. By doing so, the optimization of the university and college teaching management system can gain a solid foundation, and a high quality teaching management team can be built up ${ }^{[3]}$. It also reflects the core of the teaching mission under the knowledge-driven economic conditions in the 21st century. The optimization of the university and college teaching management team can influence the optimization of the university and college teaching management system. The two complement and reinforce each other.

\section{OPTIMIZATION OF THE UNIVERSITY AND COLLEGE TEACHING MANAGEMENT TEAM BUILDING}

\section{A. $\quad 3.1$ Enhance and emphasize on the university and college teaching management team building}

The optimization of the university and college teaching management team building contributes to China's objective of rejuvenating through education. However, a high-quality university and college teaching management team with high management expertise is the prerequisite for the improvement of higher education, teaching and management level. Thus, the university and college high-level should stress on strengthening the university and college teaching management team building, striving for the building of an optimized management team with the high qualities and skills, reasonable structure and innovational spirit. Besides, the management team should establish the concept of "putting people in the first place," attach great importance to the exchange and interaction between teaching managers of all levels and provide a favorable teaching environment for higher education and teaching. What's more, leaders of all levels should focus on the monitoring and supervision of the teaching management team, optimize the management quality, handle the superior-subordinate coordination relationship and build a vigorous teaching management team. All these could lay a solid foundation for the realization of the strategy of rejuvenating the country through education ${ }^{[4]}$.

\section{B. Optimization of the qualities and skills cultivation of the management personnel}

To improve qualities is an important guarantee for achieving the optimization of the university and college teaching management team. To enhance the qualities and skills cultivation of the university and college teaching management team is an important issue to the improvement of the management level. Leaders of all levels should pay great attention to the cultivation in this aspect. The cultivation model should get rid of shackles of the traditional degree and the profession skills. Modern university and college teaching management team requires the management personnel to equip themselves with comprehensive knowledge in all aspects. Human-care management concepts and harmonious management methods are becoming required qualities of the modern higher education managers. Long-term exposure to the training of humanistic concepts and government policy orientation can lead managers to create a more comprehensive and excellent management team. China's universities and colleges should put in place a learning and training system targeted at the current management personnel, expand the training scope and enhance theoretical knowledge learning. For example, the higher education and teaching management personnel can enrich their knowledge in terms of psychology, pedagogy and management science, improve their management expertise, master the basic teaching principles of higher education, learn the basic teaching rules and methods of higher education. Enhancement of the theoretical research into higher education management

Theoretical innovation is an important guarantee for quality improvement. The popularization of China's higher education has reached an unprecedented level, so there are no theoretical references at present. Due to China's special historical background, China's university and college teaching management team calls for further exploration of scientific theoretical knowledge, accumulation of practical experiences and careful summary and analysis of practical management experiences. To build a set of teaching management practical rules in line with the Chinese characteristics and to regularly organize the teaching management seminars within the university and college teaching management team are necessary for the improvement of the self-qualities of the management personnel; to enhance external communication and to learn 
from the successful teaching management experiences from the brotherly colleges and universities are the must-taken approach; to expand the higher education management experience exchange and to realize the higher education management resource sharing are an important guarantee for the optimization of the university and college teaching management team. Through theoretical exchange, the higher education management theoretical system can be put in place; the problems existing in the higher education and teaching management process and the solution plans can be found out so as to improve the management quality and promote the development of higher education ${ }^{[5]}$.

\section{Realization of the people-oriented teaching management}

With the continuous social progress, the enterprized management has become the prevailing choice because of the people-oriented management model of enterprises. During the higher education management process, the people-oriented management has been recognized by many education managers. Humans are objects of teaching management. The people-oriented teaching management can lead to the formation of people-oriented teaching management methods. The people-oriented teaching management means to show full respect to people, understand people, care about people and stimulate people to fight for the shared goal of schools and individuals through an inspiring environment. The university and college teaching management team should emphasize on the internal management of management, and integrate people-oriented concepts into the higher education management, enhance the human-care management, deepen the people-oriented management concepts and scientifically promote the scientific development of higher education and teaching.

\section{CONCLUSIONS AND SUGGESTIONS}

1) The optimization of the university and college management team building is a guarantee to the improvement of the higher education quality. The development history of higher education shows the imperativeness to optimize the university and college teaching management team;

2) The emphasize and strengthen the higher education and teaching management team building is the prerequisite for the improvement of the comprehensive qualities of the management team;

3) Enhance the theoretical research of higher education management, stress on intercollegiate exchange, strengthen the theoretical innovation of higher education and realize the intercollegiate theoretical resource sharing.

4) Higher education management should stress on and enhance the people-oriented concepts and promote harmonious co-existence to reach the goal of improving higher education management level.

\section{REFERENCES}

[1] Chen Yaohui.The Discussion on Specialization Construction ofthe TeachingManagement Team $\mathrm{s}$ in Colleges and Universities[J].Education and Teaching Research,2009(11):52-54.

[2] Zhang Xiaolin.On the Teaching Management Team Construction in Private Colleges[J].Value Engineering,2014(30):293-294.

[3] Liu Bo. The Meager Opinion on the Construction of Teaching Administration Team in University[J]. Journal of Changchun Normal University,2014(12):108-110.

[4] XueGuozhen.Practice and Reflection on Two-Level Model of Teaching Managementin University[J].Theory and Practice of Education,2012(12):12-14.

[5] Yang Wenshuang. Reflections on Strengthening the Construction ofTeaching Management Team in Universities[J]. Journal of Baicheng Normal University,2012(2):83-85. 